\title{
Screening for immune-potentiating antigens from hepatocellular carcinoma patients after radiofrequency ablation by serum proteomic analysis
}

Shunli Shen ${ }^{1 \dagger}$, Hong Peng ${ }^{2 \dagger}$, Ye Wang ${ }^{3+}$, Ming Xu ${ }^{3,4}$, Manxia Lin ${ }^{3,4}$, Xiaoyan Xie ${ }^{3,4}$, Baogang Peng ${ }^{1}$ and Ming Kuang ${ }^{1,3^{*}}$

\begin{abstract}
Background: Radiofrequency ablation (RFA) can not only effectively kill hepatocellular carcinoma (HCC) tumour cells but also release tumour antigens that can provoke an immune response. However, there is no consensus regarding which antigens could constitutively be generated after RFA and could potentiate the immune response. The aim of this study was to identify these immune-potentiating antigens.

Methods: We performed two-dimensional electrophoresis (2-DE) and MALDI-TOF-MS/MS analyses on serum obtained before and after RFA from 5 HCC patients. Further validation for selected proteins was performed utilizing ELISA analysis on another 52 HCC patients. Disease-free survival (DFS) analysis according to the differential expression of the interested protein before and after RFA was performed.

Results: Twelve decreased and 6 increased proteins after RFA were identified by MS. Three proteins, including clusterin, Ficolin-3, and serum retinol binding protein-4, were further verified by ELISA on the 52 HCC patients. Only Ficolin-3 proved to be significantly changed after RFA. The 52 patients were divided into two groups according to the expression of Ficolin-3 before and after RFA. The 1-, 2- and 3-year DFS rates were $59.1 \%, 31.8 \%$, and $22.7 \%$, respectively, for patients in the low Ficolin-3 group (22 patients) and 73.3\%, 60.0\%, and 50.0\%, respectively, for patients in the high Ficolin-3 group (30 patients) $(P=0.038)$.
\end{abstract}

Conclusions: In conclusion, Ficolin-3 was overexpressed in the serum of most HCC patients after RFA. Ficolin-3 might be a biomarker for RFA treatment efficacy and a potential target for HCC immunotherapy.

Keywords: Hepatocellular carcinoma, Radiofrequency ablation, Proteomics, Ficolin-3, Immunotherapy

\section{Background}

Hepatocellular carcinoma (HCC) is the fifth most common malignancy and the third leading cause of cancer-related deaths worldwide, occurring most frequently in the setting of chronic liver injury and cirrhosis. Despite improvements

\footnotetext{
* Correspondence: kuangminda@hotmail.com

${ }^{\dagger}$ Equal contributors

'Department of Liver Surgery, The First Affiliated Hospital, Sun Yat-sen University, 58 Zhongshan Road 2, Guangzhou 510080, People's Republic of China

${ }^{3}$ Division of Interventional Ultrasound, The First Affiliated Hospital, Sun Yat-sen University, 58 Zhongshan Road 2, Guangzhou 510080, People's Republic of China

Full list of author information is available at the end of the article
}

in the diagnostic and treatment modalities, the long-term prognosis has been far from satisfactory $[1,2]$.

Radiofrequency ablation (RFA) has been established as the primary ablative modality for HCC. However, similar to other treatments, RFA for HCC is frequently followed by tumour recurrence [3]. There is an urgent need to develop novel therapies with systemic activity to avoid spontaneous progression or recurrence of HCC. Immunotherapy represents a potential therapeutic option.

It has been shown that RFA can not only effectively kill HCC tumour cells but also provoke the immune response to remove the debris $[4,5]$. At temperatures above $45^{\circ} \mathrm{C}$ to $50{ }^{\circ} \mathrm{C}$, cell membranes are destroyed, proteins are denatured, 
and a region of necrosis surrounding the electrode is generated [6]. Hyperthermia-related tumour antigenicity suggests that thermal ablation-inactivated tumour tissues are endowed with immunogenicity, which might be closely related to the necrotic tumour cell-released molecules with high antigenic characteristics. In addition, the inflammatory response resulting from tumour necrosis following thermal ablation may lead to the accumulation of a large number of antigen-presenting cells (APCs) and lymphocytes at the treatment sites. These necrotic tumour cellactivated APCs, which are more dynamic than those activated by apoptotic cells, can more effectively promote the effect of antigen presentation to effector cells $[7,8]$.

Therefore, RFA favours immune activation and the presentation of otherwise cryptic antigens, thus inducing a specific anti-tumour immune response. However, unfortunately, there is no consensus regarding which antigens could constitutively be generated after RFA and could potentiate the immune response.

To identify the immune-potentiating antigens, proteomic analysis with two-dimensional electrophoresis (2-DE) and mass spectrometric analysis (MS) was used in this study. We found that Ficolin-3 was overexpressed in the serum of most HCC patients after RFA. In addition, elevated Ficolin-3 predicts better prognosis, which might be a biomarker for RFA treatment efficacy and a potential therapeutic target for HCC immunotherapy.

\section{Methods}

\section{HCC patients}

This study was performed according to the guidelines of the Helsinki Declaration. It was registered and approved by the ethics committee at The First Affiliated Hospital of Sun Yat-sen University. All patients provided written informed consent before treatment. The serum samples were collected from 57 primary $\mathrm{HCC}$ patients who underwent RFA treatment at the First Affiliated Hospital of Sun Yat-sen University between January 2012 and March 2013. All patients underwent abdominal ultrasound and computed tomography (CT) or magnetic resonance imaging (MRI), chest X-ray or CT before RFA. All of these patients were more than 18 years of age with complete clinical and laboratory data. Patients who received preoperative chemotherapy or radiotherapy were excluded. In addition, no patient had coexistent haematologic disorders or known active infection before treatment, ensuring that the serum parameters tested were representative of the normal baseline value. Specimens were obtained with informed consent from all patients. Sera were collected before RFA and 7 days after RFA from each patient. Fine needle biopsy was carried out on each patient before RFA. All patients were histologically diagnosed with HCC. Patients with mixed HCC and cholangiocarcinoma or without full follow-up data were excluded.

\section{Sample preparation for proteomic analysis}

The blood samples of 5 of the 57 HCC patients were collected into clean glass tubes without an additive and were allowed to clot at room temperature for $60 \mathrm{~min}$. Serum was separated by centrifugation at $1000 \mathrm{x} g$ for $30 \mathrm{~min}$ to remove the insoluble solids. Aliquots of serum were then stored at $-80{ }^{\circ} \mathrm{C}$ until use. The removal of albumin and IgG was performed using the ProteoPrep Blue Albumin Depletion kit (Sigma, St. Louis, MO, USA), according to the manufacturer's instructions. The 2-D cleanup kit (GE Healthcare, UK) was used to remove impurities from the protein extraction prior to the determination of the sample concentration using the 2-D Quant kit (GE Healthcare).

\section{2-de}

Proteins derived from 5 samples before and after RFA were pooled separately, and 2-DE was performed three times per sample to minimize gel-to-gel variations. The Immobiline Dry strip ( $\mathrm{pH} \mathrm{4-7} \mathrm{L,} \mathrm{length} 18 \mathrm{~cm}$; GE Healthcare) was immersed with $120 \mu \mathrm{g}$ of proteins in $350 \mu \mathrm{l}$ of rehydration buffer containing $5 \mathrm{M}$ urea, $1 \mathrm{M}$ thiourea, 4\% CHAPS, $65 \mathrm{mM}$ dithiothreitol, $5 \mathrm{mM}$ tributylphosphine, 1\% IPG buffer, and $1 \mathrm{mM}$ phenylmethylsulphonyl fluoride. Isoelectric focusing (IEF) was performed using an IPGphor IEF apparatus with $0.002 \%$ bromophenol blue for $14 \mathrm{~h}$ at room temperature (GE Healthcare) at $70 \mathrm{kVh}$. The strip was then subjected to two-step equilibration in equilibration buffer containing $6 \mathrm{M}$ urea, 30\% glycerol, $2 \%$ SDS and $50 \mathrm{mM}$ Tris- $\mathrm{HCl}(\mathrm{pH} 6.8)$ with $2 \%$ dithiothreitol $(w / v)$ for the first step and $2.5 \%(\mathrm{w} / \mathrm{v})$ iodoacetamide for the second step. The two-dimensional SDS-PAGE gel $(12.5 \% \mathrm{~T}, 18 \times 16 \times 0.015 \mathrm{~cm})$ was run at $7 \mathrm{~W}$ for $30 \mathrm{~min}$ followed by $17 \mathrm{~W}$ for $4 \mathrm{~h}$. Separated proteins were stained with Deep Purple fluorescence dye (GE Healthcare; 1:200 diluted in $100 \mathrm{mM}$ borate buffer) at room temperature for $1.5 \mathrm{~h}$ and then were rinsed 3 times ( 5 min each) with deionized water. The resolved protein spots in individual stained 2-D gels were visualized using a Typhoon 9200 laser scanner (GE Healthcare).

\section{In-gel enzymatic digestion}

ImageMaster 2-D Elite software 5.0 (GE Healthcare) was used for image analysis, which included spot detection, quantification and normalization. The intensity volume of each spot was normalized with the total intensity volume (summation of the intensity volumes obtained from all spots within the same 2-D gel) and was expressed as the relative intensity. In-Gel Enzymatic Digestion Protein spots were excised from the gel with an Ettan 
Spot Picker (version 1.0, GE Healthcare), destained twice with $30 \mathrm{mM}$ potassium ferricyanide and $100 \mathrm{mM}$ sodium thiosulphate $(1: 1, v / \mathrm{v})$ and then equilibrated in $50 \mathrm{mM}$ $\mathrm{NH}_{4} \mathrm{HCO}_{3}$ to $\mathrm{pH}$ 8.0. After dehydration with acetonitrile $(\mathrm{ACN})$ and drying in a speed vacuum concentrator for $20 \mathrm{~min}$, the gel pieces were rehydrated in a minimal volume of sequencing grade porcine trypsin (Promega) solution $\left(20 \mu \mathrm{g} / \mathrm{ml}\right.$ in $\left.25 \mathrm{mM} \mathrm{NH} \mathrm{mCO}_{3}\right)$ and were incubated at $37{ }^{\circ} \mathrm{C}$ overnight. The peptides were extracted twice using $0.1 \%$ TFA in $50 \%$ ACN and were completely dried in a speed vacuum concentrator.

\section{Protein identification and database searching}

MALDI-TOF-MS/MS identification and database searching protein identification were performed using an Ultraflex III mass spectrometer (Bruker Daltonics, Bremen, Germany) operated in the reflectron mode at an accelerating voltage of $20 \mathrm{kV}$. A saturated solution of $\alpha$-cyano-4-hydroxycinnamic acid in 50\% ACN and 0.1\% TFA was used as the matrix. Peptide mass fingerprints and MS/MS analysis were searched using BioTools software (version 3.0, Bruker Daltonics, Germany) against the SwissProt protein database. Protein identification was accepted when the peptide score was higher than the threshold value $(P<0.05)$, and manual interpretation had to confirm the agreement between the spectra and peptide sequence.

\section{Enzyme-linked immunosorbent assay (ELISA) analysis} The levels of Clusterin (CLU) (E91180Hu; Cloud Clone Co.), Ficolin-3 (FCN3) (E91903Hu; USCN), and retinol binding protein 4 (RBP4) (E90929Hu; Cloud Clone Co.) in serum were measured using ELISA according to the manufacturer's instructions. After development with a chromogen-substrate solution, the reaction was terminated by adding $100 \mu \mathrm{l}$ of stop solution. Optical density values were read at $450 \mathrm{~nm}$, and the concentrations were automatically calculated according to the standard curve.

\section{Follow-up}

Patients were regularly followed up at outpatient clinics every month for the first half year, every 3 months for the next one and a half years, and once annually thereafter. Patients received a physical examination, liver ultrasound, chest X-ray and serum alpha foetal protein (AFP) test at each follow-up. Abdominal computed tomography (CT) was performed every 6-12 months or when recurrence was suspected. Recurrence was defined as the emergence of clinical, radiological, and/or pathologic diagnosis of tumours from a previous origin locally or distantly. Once recurrence was confirmed, salvage treatments, including percutaneous ablation, surgery, or transcatheter arterial chemoembolization (TACE) were selected as needed.

\section{Statistical analysis}

Statistical analysis was performed using SPSS statistical software (SPSS Inc., Chicago, IL, USA, version 16.0 for Windows). Student's $t$-test and one-way analysis of variance (ANOVA) were used to analyse differences between groups. Disease-free survival (DFS) was calculated from the date of RFA to the date of recurrence. Survival curves were plotted using the Kaplan-Meier method and were compared using the log-rank test. A $P$-value $<0.05$ was considered statistically significant.

\section{Results}

\section{Patient and tumour characteristics}

There were 49 (86.0\%) male and 8 (14\%) female patients. The mean age of the patients was $55.8 \pm$ 12.6 years (range: 30-76 years). Hepatitis B surface antigen (HBsAg) was positive in 50 patients $(87.7 \%)$. Increased AFP (> $20 \mathrm{ng} / \mathrm{ml})$ was found in 34 cases (59.6\%). Sixteen $(28.1 \%)$ patients had more than one tumour in the liver with a mean tumour size (greatest dimension) of $2.7 \pm 0.8 \mathrm{~cm}$ (range: $1-4.4 \mathrm{~cm}$ ). Thirty-two patients (56.1\%) developed recurrence and 21 (36.8\%) died during follow-up.

\section{Proteomic analyses identified differentially expressed serum proteins after RFA}

Representative gel images of the protein are shown in Fig. 1. A comparison of the 2-DE images revealed that 18 protein spots (A1-A18) were down-regulated (Fig. 2) and 16 protein spots (B1-B16) were up-regulated after RFA (Fig. 3), in which 12 and 6 protein spots changed more than two-fold, respectively. We next identified these 18 differentially expressed host-specific proteins by mass spectrometry, including 12 proteins that were decreased after RFA and 6 proteins that were increased after RFA treatment (Table 1). Finally, three of these candidates were found to be possibly immunoreactive through document review: CLU, Ficolin-3 and RBP4 [9, 10].

\section{ELISA analysis}

We further expanded our sample size and validated the differential expression of CLU, Ficolin-3 and RBP4 in sera from another 52 samples using ELISA. The mean values of CLU, Ficolin-3 and RBP4 before and after RFA were $121.9 \pm 21.5 \mathrm{Vs} 92.9+11.1 \mu \mathrm{g} / \mathrm{ml}$ (range: 5.008 to $1087.0 \mu \mathrm{g} / \mathrm{ml}$ ), $110.4+11.4 \mathrm{Vs} 289.7+87.4$ (range: 4.34 to $4630 \mu \mathrm{g} / \mathrm{ml}$ ), and $71.6+2.9 \mathrm{Vs} 64.4+3.0$ (range: 6.6 to $93 \mu \mathrm{g} / \mathrm{ml})$, respectively. Through comparison of the serum levels of the above 3 proteins before and after RFA, only Ficolin-3 showed a significant difference $(P<0.05)$ (Fig. 4).

\section{Survival analysis}

Fifty-two patients were divided into two groups according to the expression mode of Ficolin-3. Thirty patients with 

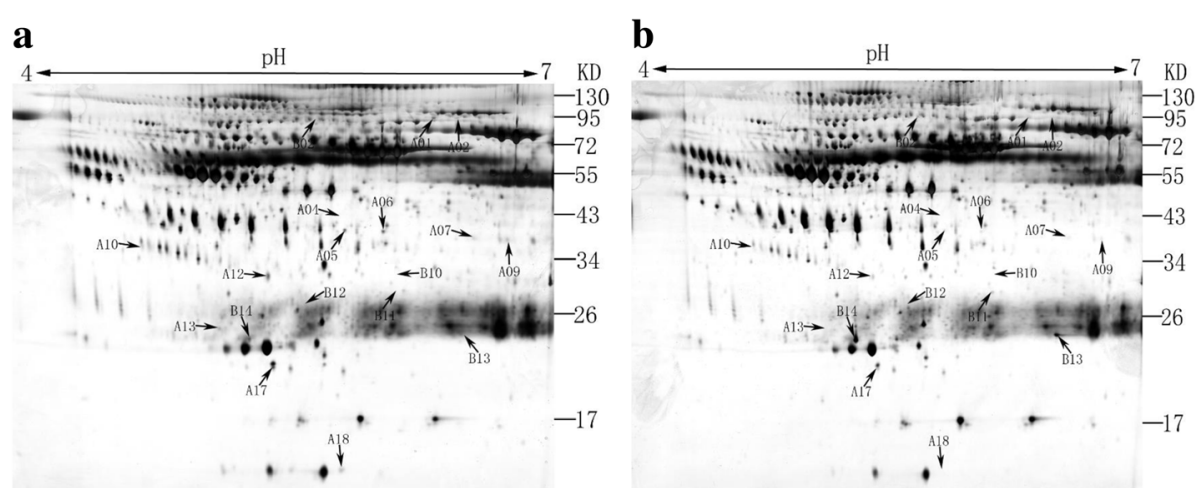

Fig. 1 Representative 2-DE serum protein profiles before and after RFA treatment for hepatocellular carcinoma patients. These differentially expressed protein spots (labelled as A1 to A18 and B2 to B14) were subsequently identified by MALDI-TOF MS/MS analyses

elevated Ficolin-3 after RFA were divided into the high Ficolin-3 group, while 22 patients with decreased Ficolin-3 after RFA were divided into the low Ficolin-3 group. Basic clinical characteristics including gender, age, Child-Pugh staging, AFP level, tumour size and tumour number between the two groups showed no significant difference $(\mathrm{P}<0.05)$. The 1 -, 2 - and 3-year DFS rates were $59.1 \%, 31.8 \%$, and $22.7 \%$ for patients in the low Ficolin3 group and $73.3 \%, 60.0 \%$, and $50.0 \%$ for patients in the high Ficolin-3 group. $(P=0.038)$ (Fig. 5).

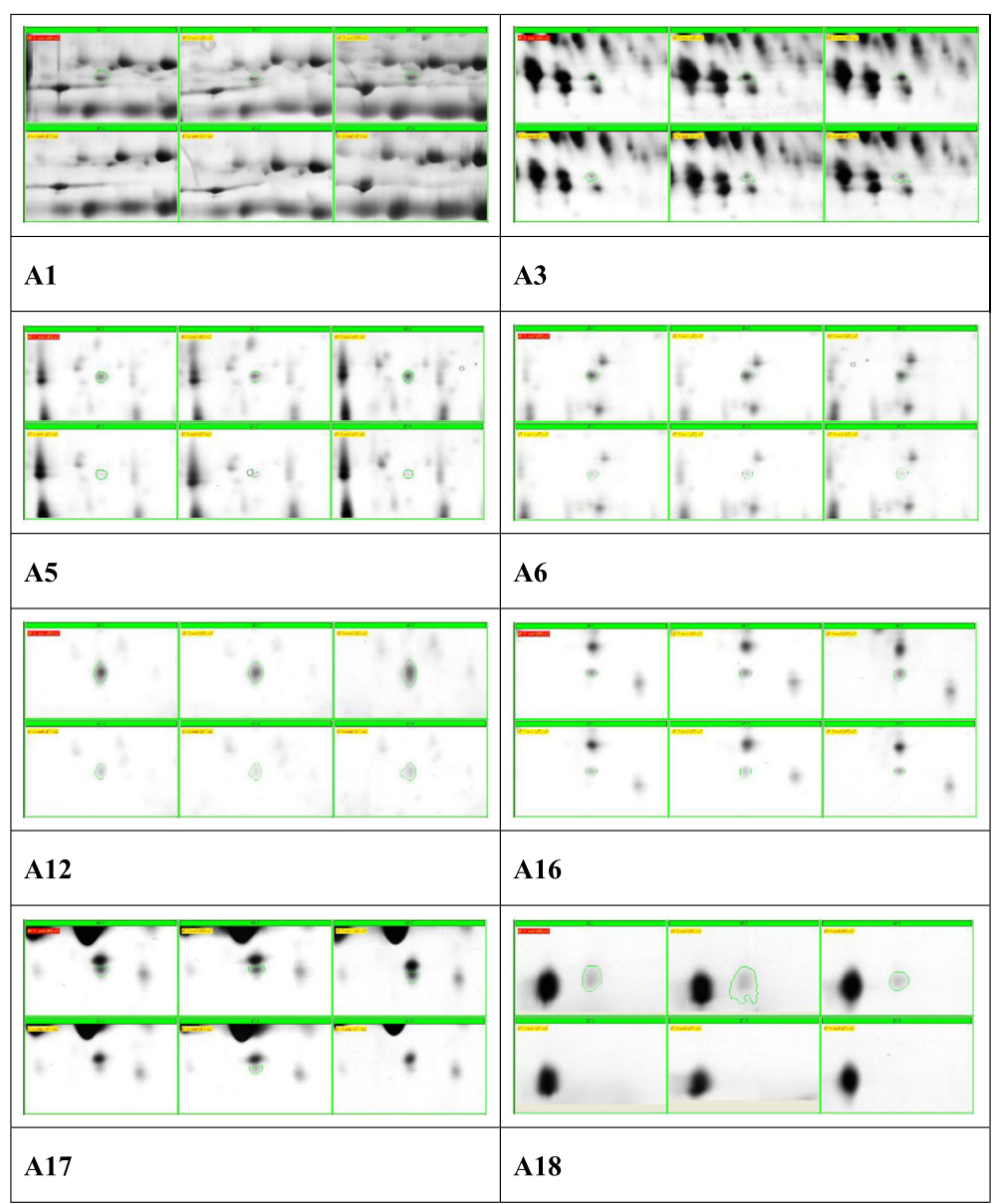

Fig. 2 Protein spots decreased after RFA 


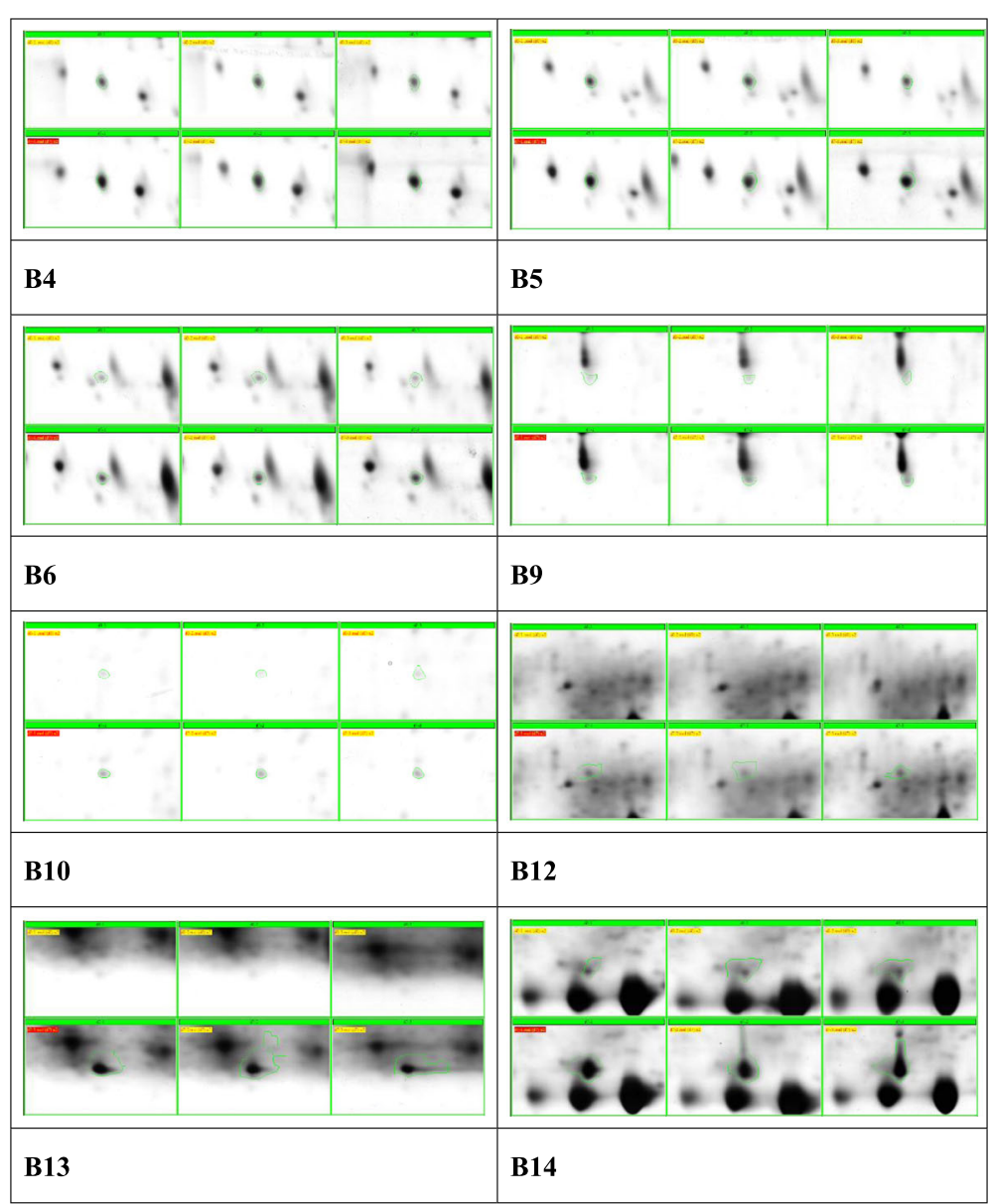

Fig. 3 Protein spots increased after RFA

\section{Discussion}

RFA is a minimally invasive technique used as standard local therapy for HCC. Its immune-potentiating effect has been frequently reported with few studies concentrating on the exact mechanisms. In the present study, we performed a gel-based serum proteomic analysis before and after RFA for HCC patients and identified 18 proteins to be differentially expressed by mass spectrometry. Through literature review, we found three proteins, CLU, Ficolin-3, and RBP4, that might be related to an immune response. Further ELISA assay showed that only Ficolin-3 significantly changed after RFA. Survival analysis showed that patients with higher Ficolin-3 after RFA tended to have better DFS, indicating that Ficolin-3 might be one of the immune-potentiating tumour antigens.

The exact explanation for the association between the enhanced immune response and RFA is not fully clarified. There are several possible explanations. First, RFA destroyed the tumour and relieved the body of the tumour burden, possibly leading to the reversal of immune suppression and unmasking a population of primed tumour-specific $\mathrm{T}$ cells that can mediate protective immunity [11]. Second, RFA leads to enhanced release and exposure of immune-potentiating tumour antigens, such as nuclear protein high mobility group B1 and heat shock proteins (HSPs), which might induce the antitumour immune response through the activation of dendritic cells (DCs) [12]. At 24 h after percutaneous treatment of HCC by thermal ablation, the expression of HSP70 in the cytoplasm and on the cell membrane of tumour cells was augmented by 8 times and that of HSP90 was augmented by 1.2 times. The two HSPs are evidently antigenic stimulatory to the immune system [13]. The anti-tumour effect of in vitro-inactivated vaccine is comparatively weak, which might be due to the rinsing of many immunogens (such as HSP) released by necrotic tumour cells during multiple centrifugal washing processes, resulting in immunogenicity decline of the tumour cells finally collected. This indirectly proves the effectiveness of the anti-tumour immune response stimulated by tumourassociated antigens released in situ from tumour tissues following thermal ablation. Ficolin-3 might be one of these in situ-released antigens. Third, hyperthermia induced by RFA causes both immunologic and biologic 
Table 1 Protein identification using MALDI-TOF MS/MS

\begin{tabular}{|c|c|c|}
\hline No. & gil & Protein name \\
\hline$\overline{\mathrm{A} 01}$ & $251,837,060$ & $\begin{array}{l}\text { Chain D, Cobra Venom Factor (Cvf) In Complex } \\
\text { With Human Factor B }\end{array}$ \\
\hline $\mathrm{A} 02$ & $110,590,599$ & $\begin{array}{l}\text { Chain A, Apo-Human Serum Transferrin } \\
\text { (Glycosylated) }\end{array}$ \\
\hline $\mathrm{A} 04$ & $78,174,390$ & HP protein \\
\hline A05 & $220,702,427$ & $\begin{array}{l}\text { Chain B, Crystal Structure Of Bbetad432a Variant } \\
\text { Fibrinogen Fragment D With The Peptide Ligand } \\
\text { Gly-His-Arg-Pro-Amide }\end{array}$ \\
\hline A06 & $7,770,217$ & PRO2675 \\
\hline $\mathrm{A} 07$ & $49,258,810$ & $\begin{array}{l}\text { Chain A, Human Serum Transferrin, N-Lobe Bound } \\
\text { With Oxalate }\end{array}$ \\
\hline A09 & $158,254,550$ & unnamed protein product \\
\hline A10 & $193,787,502$ & unnamed protein product \\
\hline $\mathrm{A} 12$ & $32,891,795$ & $\begin{array}{l}\text { clusterin (complement lysis inhibitor, SP-40,40, } \\
\text { sulfated glycoprotein 2, testosterone-repressed } \\
\text { prostate message 2, apolipoprotein J) }\end{array}$ \\
\hline A13 & $86,439,006$ & immunoglobulin lambda light chain \\
\hline A17 & $7,770,173$ & PRO2222 (RBP4) \\
\hline A18 & $212,374,952$ & $\begin{array}{l}\text { Chain A, Crystal Structure Of Transthyretin Variant } \\
\text { V20 s }\end{array}$ \\
\hline B02 & $2,781,209$ & Chain C, Crystal Structure Of Fibrinogen Fragment D \\
\hline B10 & $3,413,516$ & Hakata antigen (H-ficolin) \\
\hline B11 & $119,626,073$ & albumin, isoform CRA_j \\
\hline B12 & 576,259 & $\begin{array}{l}\text { Chain A, The Structure Of Pentameric Human Serum } \\
\text { Amyloid P Component }\end{array}$ \\
\hline B13 & $149,673,887$ & immunoglobulin light chain \\
\hline B14 & $170,684,606$ & immunoglobulin kappa 1 light chain \\
\hline
\end{tabular}

effects, such as the accelerated migration of peripheral blood mononuclear cells, activation of effector cells, and induction and secretion of cytokines, all of which might enhance the antitumour immune response [14]. Hyperthermia-killed HCC cells express a large number of HSPs. Compared with tumour cells untreated with heat shock, hyperthermia-treated ones have sensitized dendritic cell vaccines more effective in inducing $\mathrm{CD} 4^{+}$ and $\mathrm{CD}^{+} \mathrm{T}$ cells to participate in the anti-tumour immune response [15]. In addition, $\mathrm{HCC}$ ablation induces a functional transient activation of myeloid dendritic cells (MDC) associated with increased serum levels of TNF- $\alpha$ and IL-1 $\beta$ [16].

We found that serum Ficolin-3 was significantly overexpressed after RFA, which was verified by ELISA in 52 specimens. Furthermore, we found that patients with higher Ficolin-3 after RFA had better 1-, 3-, and 5- year DFS. However, no significant difference was found for CLU and RBP4. Ficolin-3 (H-ficolin; Hakata antigen) is a thermolabile beta-2-macroglycoprotein found in all human sera and is a member of the ficolin/opsonin p35 lectin family. The protein can activate the complement pathway in association with MASPs and SMAP, thereby aiding in the host defence through the activation of the lectin pathway [17]. It was found that a low concentration of Ficolin-3 was associated with an increased risk of fever and neutropenia (FN), particularly FN with bacteraemia, in children treated with chemotherapy for cancer [18]. In addition, Ficolin-3 was found to bind to IgMs, and the IgM-Ficolin-3 complex deposited on cancer cells could induce complement attack. Therefore, the IgM-Ficolin-3 -mediated complement activation pathway might be a new defensive strategy for human cancer immunosurveillance. These two studies showed that high Ficolin-3 represents strong immunity against infection or cancer. We proposed this might be one of the reasons for better survival for HCC patients with higher serum Ficolin-3 after RFA.

Because the immune-potentiating effect of thermal ablation is not sufficiently strong to prevent tumour recurrence, there is an urgent need to develop novel therapies with systemic activity to avoid spontaneous progression or recurrence after RFA treatment [19]. In a rabbit VX2 hepatoma model, it was found that combined RFA and Toll-like receptor 9 (TLR9) agonist stimulation not only induced increased antitumour T-cell stimulation/ cytotoxicity and a longer mean survival of animals but also significantly inhibited tumour spread to the lungs and peritoneum and prohibited new tumour growth in animals receiving a secondary systemic tumour cell injection [20]. In HCC patients, Cui et al. found that cellular immunotherapy (CIT) with autologous mononuclear
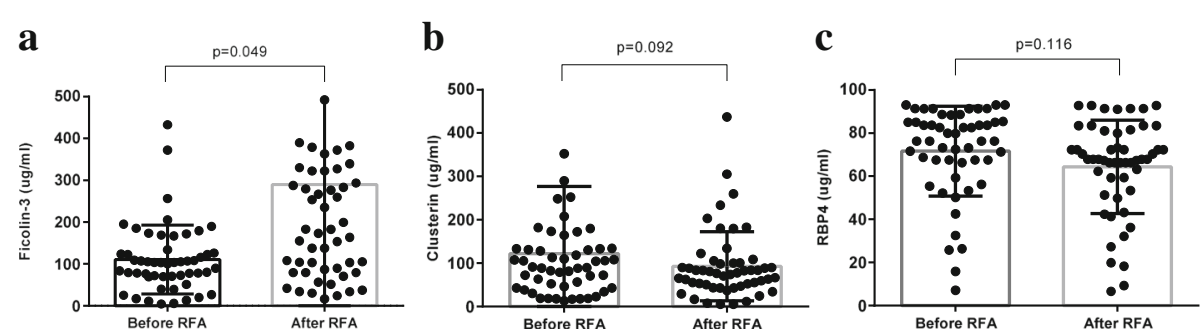

Fig. 4 Ficolin-3, CLU and RBP4 levels in serum before and after radiofrequency (RFA) was compared in a validation set of 52 patients using ELISA. Results are expressed as the mean \pm SD. A $P$-value $<0.05$ was considered statistically significant 
Survival Functions

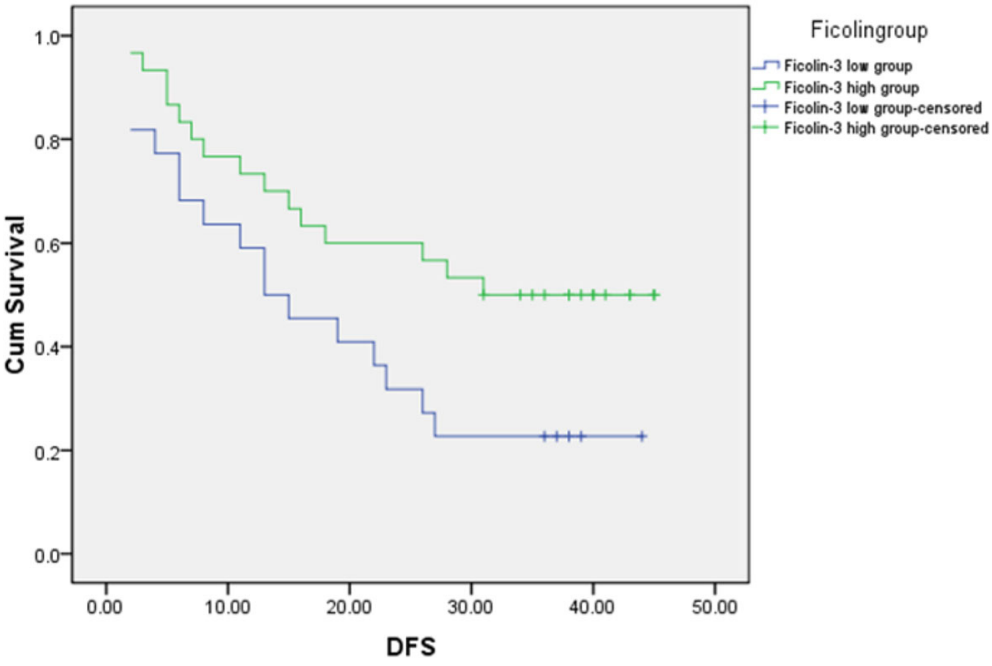

Fig. 5 Disease-free survival of HCC patients after RFA according to the expression level of Ficolin-3

cell-derived natural killer (NK) cells, $\gamma \delta \mathrm{T}$ cells and cytokine-induced killer (CIK) cells could enhance progression-free survival for HCC patients after RFA with no adverse response [21]. den Brok et al. found that RFA induced a weak immune response, but it was not sufficient to protect against tumour recurrence. Therefore, they combined immune-potentiating strategies via the administration of CTLA-4-blocking antibodies to lower the threshold for T-cell activation and obtained a better immune response, finally leading to increased tumour protection [22]. Actually, we conceived the same idea as den Brok that tumour antigens released by tumours in situ or in the serum might induce an antitumour immune response, leading to a better prognosis, and Ficolin-3 might be one of those antigens.

Our study possesses limitations. First, in this study, we tried to identify immune-potentiating tumour antigens released after RFA, but we could only find antigens soluble in serum instead of other tumour antigens in situ. It would have been more ideal to have used ablated tumour tissues in this study. However, in clinical practice, it is very difficult to obtain sufficient tumour antigens. This idea is undoubtedly possible in animal models, although it would not reflect the true circumstance. Second, most of the HCC patients were HBV associated in the present study. Thus, it remains to be verified in what type of model would Ficolin-3 change after RFA using other hepatitis-associated HCC samples. Additionally, although we found that Ficolin-3 might be used as a tumour vaccine for the prevention and therapy of residual tumour through stimulation of the immune system, we have not proven this hypothesis, which we hope to confirm in a future animal study or even with preclinical tests.

\section{Conclusions}

We found that Ficolin-3 was overexpressed in the serum of most HCC patients after RFA and might be a potential biomarker for RFA treatment efficacy and tumour vaccine development for HCC immunotherapy. The combination of RFA and active immunotherapy with Ficolin-3 may have a synergistic effect in HCC treatment.

\section{Abbreviations}

2D-DIGE: Two-dimensional difference gel electrophoresis; 2-DE: Two-dimensional electrophoresis (2-DE); ACN: Dehydrated with acetonitrile; AFP: Alpha foetal protein; ANOVA: One-way analysis of variance; APCs: Antigen-presenting cells (APCS); CIK cell: Cytokine-induced killer cell; CIT: Cellular immunotherapy; CLU: Clusterin; DFS: Disease-free survival; ELISA: Enzyme-linked immunosorbent assay; FCN3: Ficolin-3; FN: Fever and neutropenia; HCC: Hepatocellular carcinoma; HMGB1: Nuclear protein high-mobility group B1; HSPs: Heat shock proteins; IEF: Isoelectric focusing; MDC: Myeloid dendritic cells; MS: Mass spectrometric analysis; NK cell: Natural killer cell; RBP4: Retinol binding protein 4;

RFA: Radiofrequency ablation; TACE: Transcatheter arterial chemoembolization; TLR9: Toll-like receptor 9

\footnotetext{
Acknowledgements

N/A.

\section{Funding}

This study was funded by the grants from the National Natural Science Foundation of China (81272312 and 81071892), Science and Technology Project of Guangzhou (2014Y2-00129), Natural Science Foundation of Guangdong Province (2014A030313108), and Fundamental Research Funds for the Central Universities (09ykpy30, 15ykpy15). The funders had no role in the study design, data collection and analysis, decision to publish, or preparation of the manuscript.
}

\section{Availability of data and materials}

All data supporting the findings in this study are included within the manuscript. 


\section{Authors' contributions}

Due to their very high levels of contribution to this work, SLS, HP and YW are considered first authors; SLS, HP and YW collected the specimens and conducted 2-DE. MX and MXL performed ELISA; SLS and YW prepared all of the figures; XYX, BGP and MK were responsible for the project planning, data analysis and manuscript preparation; and all of the authors wrote the main manuscript and reviewed it. All authors read and approved the final manuscript.

\section{Ethics approval and consent to participate}

This study was performed according to the guidelines of the Helsinki Declaration. It was registered and approved by the ethics committee at The First Affiliated Hospital of Sun Yat-sen University. All patients provided written informed consent before treatment.

\section{Consent for publication}

N/A

\section{Competing interests}

The authors declare that they have no competing interests.

\section{Publisher's Note}

Springer Nature remains neutral with regard to jurisdictional claims in published maps and institutional affiliations.

\section{Author details}

'Department of Liver Surgery, The First Affiliated Hospital, Sun Yat-sen University, 58 Zhongshan Road 2, Guangzhou 510080, People's Republic of China. ${ }^{2}$ Department of Bilio-pancreatic Surgery, The First Affiliated Hospital, Sun Yat-sen University, 58 Zhongshan Road 2, Guangzhou 510080, People's Republic of China. ${ }^{3}$ Division of Interventional Ultrasound, The First Affiliated Hospital, Sun Yat-sen University, 58 Zhongshan Road 2, Guangzhou 510080 People's Republic of China. ${ }^{4}$ Department of Medical Ultrasonics, The First Affiliated Hospital, Sun Yat-sen University, 58 Zhongshan Road 2, Guangzhou 510080, People's Republic of China.

\section{Received: 4 October 2016 Accepted: 21 January 2018}

\section{Published online: 31 January 2018}

\section{References}

1. Bruix J, Sherman M. Management of hepatocellular carcinoma. Hepatology. 2005;42(5):1208-36.

2. El-Serag HB. Hepatocellular carcinoma. N Engl J Med. 2011;365(12):1118-27.

3. Tiong L, Maddern GJ. Systematic review and meta-analysis of survival and disease recurrence after radiofrequency ablation for hepatocellular carcinoma. Br J Surg. 2011;98(9):1210-24.

4. Waitz R, Solomon SB. Can local radiofrequency ablation of tumors generate systemic immunity against metastatic disease. Radiology. 2009:251(1):1-2.

5. Wissniowski TT, Hänsler J, Neureiter D, Frieser M, Schaber S, Esslinger B, Voll R, Strobel D, Hahn EG, Schuppan D, Wissniowski TT, Hünsler J. Activation of tumor-specific T lymphocytes by radio-frequency ablation of the VX2 hepatoma in rabbits. Cancer Res. 2003:63(19):6496-500.

6. Zerbini A, Pilli M, Penna A, Pelosi G, Schianchi C, Molinari A, Schivazappa S, Zibera C, Fagnoni FF, Ferrari C, Missale G. Radiofrequency thermal ablation of hepatocellular carcinoma liver nodules can activate and enhance tumor-specific T-cell responses. Cancer Res. 2006;66(2):1139-46.

7. Kuang M, Liu SQ, Saijo K, Uchimura E, Huang L, Leong KW, Lu MD, Huang JF, Ohno T. Microwave tumour coagulation plus in situ treatment with cytokine-microparticles: induction of potent anti-residual tumour immunity. Int J Hyperth. 2005;21(3):247-57.

8. Dong BW, Zhang J, Liang P, Yu XL, Su L, Yu DJ, Ji XL, Yu G. Sequential pathological and immunologic analysis of percutaneous microwave coagulation therapy of hepatocellular carcinoma. Int J Hyperth. 2003;19(2): 119-33.

9. Chen Y, Azman SN, Kerishnan JP, Zain RB, Chen YN, Wong YL, Gopinath SC. Identification of host-immune response protein candidates in the sera of human oral squamous cell carcinoma patients. PLoS One. 2014;9(10): e109012.

10. Honoré C, Hummelshoj T, Hansen BE, Madsen HO, Eggleton P, Garred P. The innate immune component ficolin 3 (Hakata antigen) mediates the clearance of late apoptotic cells. Arthritis Rheum. 2007;56(5):1598-607.
11. Salvadori S, Martinelli G, Zier K. Resection of solid tumors reverses T cell defects and restores protective immunity. J Immunol. 2000;164(4):2214-20.

12. Fatourou EM, Koskinas JS. Adaptive immunity in hepatocellular carcinoma: prognostic and therapeutic implications. Expert Rev Anticancer Ther. 2009; 9(10):1499-510

13. Schueller G, Kettenbach J, Sedivy R, Stift A, Friedl J, Gnant M, Lammer J. Heat shock protein expression induced by percutaneous radiofrequency ablation of hepatocellular carcinoma in vivo. Int J Oncol. 2004;24(3):609-13.

14. Hansler J, Wissniowski TT, Schuppan D, Witte A, Bernatik T, Hahn EG, Strobel D. Activation and dramatically increased cytolytic activity of tumor specific $T$ lymphocytes after radio-frequency ablation in patients with hepatocellular carcinoma and colorectal liver metastases. World J Gastroenterol. 2006; 12(23):3716-21.

15. Schueller G, Stift A, Friedl J, Dubsky P, Bachleitner-Hofmann T, Benkoe T, Jakesz R, Gnant M. Hyperthermia improves cellular immune response to human hepatocellular carcinoma subsequent to co-culture with tumor lysate pulsed dendritic cells. Int J Oncol. 2003;22(6):1397-402.

16. Ali MY, Grimm CF, Ritter M, Mohr L, Allgaier HP, Weth R, Bocher WO, Endrulat K, Blum HE, Geissler M. Activation of dendritic cells by local ablation of hepatocellular carcinoma. J Hepatol. 2005;43(5):817-22.

17. Matsushita M, Kuraya M, Hamasaki N, Tsujimura M, Shiraki H, Fujita T. Activation of the lectin complement pathway by $\mathrm{H}$-ficolin (Hakata antigen). J Immunol. 2002;168(7):3502-6.

18. Schlapbach LJ, Aebi C, Hansen AG, Hirt A, Jensenius JC, Ammann RA. H-ficolin serum concentration and susceptibility to fever and neutropenia in paediatric cancer patients. Clin Exp Immunol. 2009;157(1):83-9.

19. Fagnoni FF, Zerbini A, Pelosi G, Missale G. Combination of radiofrequency ablation and immunotherapy. Front Biosci. 2008;13:369-81.

20. Behm B, Di FP, Michl P, Neureiter D, Kemmerling R, Hahn EG, Strobel D, Gress T, Schuppan D, Wissniowski TT. Additive antitumour response to the rabbit VX2 hepatoma by combined radio frequency ablation and toll like receptor 9 stimulation. Gut. 2014;65(1):134-43.

21. Cui J, Wang N, Zhao H, Jin H, Wang G, Niu C, Terunuma H, He H, Li W. Combination of radiofrequency ablation and sequential cellular immunotherapy improves progression-free survival for patients with hepatocellular carcinoma. Int J Cancer. 2014;134(2):342-51.

22. den Brok MH, Sutmuller RP, van der Voort R, Bennink EJ, Figdor CG, Ruers TJ, Adema GJ. In situ tumor ablation creates an antigen source for the generation of antitumor immunity. Cancer Res. 2004;64(11):4024-9.

\section{Submit your next manuscript to BioMed Central and we will help you at every step:}

- We accept pre-submission inquiries

- Our selector tool helps you to find the most relevant journal

- We provide round the clock customer support

- Convenient online submission

- Thorough peer review

- Inclusion in PubMed and all major indexing services

- Maximum visibility for your research

Submit your manuscript at www.biomedcentral.com/submit
Biomed Central 